\title{
METHODOLOGY OF ASSESSING INVESTMENT ATTRACTIVENESS OF UKRAINIAN GAS PRODUCERS
}

\author{
Nadiia Pysar \\ Vasyl Stefanyk Precarpathian National University \\ 57 Shevchenko str., Ivano-Frankivsk, Ukraine, 76018
}

\begin{abstract}
The development of a methodology for assessing investment attractiveness of businesses of Ukrainian gas production industry that is presented in the form of a generalized algorithm reflects the conceptual model of research. The scope of research is methodological approaches to assessing investment attractiveness of businesses. The purpose of this study is to recommend methodology for assessing the investment attractiveness of Ukrainian gas producers. The methodology for assessing investment attractiveness of gas producers can be used to determine the investment attractiveness of an individual business, evaluate financial position in the course of privatization and development of measures for rehabilitation or liquidation of a business, as well as to carry out a financial analysis at the initiative of both the business itself and investors who consider investment in production. The paper assesses performance of the leading gas producers in accordance with the individual life cycle stages of the business. The authors propose management measures to ramp up natural gas production in Ukraine. The amount of investment in the gas production industry required to achieve the estimated gas production figures has been assessed and the overriding priorities for the development of Ukrainian gas production industry have been established.
\end{abstract}

Keywords: gas production industry, energy independence, investment, management, investment attractiveness, gas production output, risk.

\section{Introduction}

The build-up of equity natural gas production is a key aspect of Ukraine's energy security. Exploration and production of natural gas require considerable amount of investment that can be compensated only by marketing of products. Thus, it is only an economically balanced closed process cycle from the prospecting and exploration of gas fields to the marketing of gas that enables the industry to develop. The natural resources potential of Ukraine's gas industry has a major impact on the level of its investment attractiveness. Therefore, there is a need to identify major issues and shortcomings, as well as consider possible ways to improve the development of the untapped potential of the gas production industry by increasing equity natural gas production and creating a congenial investment climate, which could lead to Ukraine's energy independence and strengthen its economic position in the global energy space. One of the ways to address the issue of increasing flows of investment in Ukrainian gas production industry is improving the methodological basis for determining investment attractiveness of gas producers to allow a balanced and integrated assessment of investment objects and ensure a sound investment decision-making. Since the existing methods for determining the level of investment attractiveness do not always meet the investor's needs for objective, impartial, expedient information sufficient for decision-making, we propose a methodology using various methods of relative assessment of the business's investment attractiveness subject to external and internal factors affecting the business. In an environment of natural scarcity and intense competition in obtaining financial resources, the issue of creating an investor's view of the business as an attractive investment object, i.e. generating investment attractiveness, comes to the fore.

\section{Review of Similar Research}

Economic literature widely acknowledges the approach to assessing the investment attractiveness of individual businesses (firms) based on sequencing stages of studying the investment market when developing a strategy of investment activities and forming an efficient investment portfolio.

The comprehensive assessment of the business's investment attractiveness should include all the components of this concept, namely, absolute and comparative methods for determining the attractiveness of a business as an investment object [1]. 
The principal task in channeling investment is to calculate the economic efficiency of investing in an investment object. In labor [2] is offered using the comparison method that should cover the following main components of the investment process: comparison of investment objects, entities involved in investment activities (investors) and investment conditions (investment highlights). According to the author [3], however, the aforementioned method is not enough to accurately characterize the object's investment attractiveness, but allows to make a distinction between the following methods: internal rate of return, investment return period, balance rate of profitability, profitability index, and net present value. In addition to the aforementioned indices, in labor [4] is attached out the capitalized income value (market value of the joint-stock company), i. e. the ratio of the market to book value of shares that includes a general characteristic of success or failure of the joint-stock company, the share liquidity ratio characterizing the potential sale of shares of a specific issuer, dividend yield of shares that indicates the amount of income assigned to the current consumption of shareholders relative to the market value of shares. The authors in [5] suggest using a comparative analysis technology as a special tool for the analysis of business projects to highlight the strengths and weaknesses of a specific project compared to the best project in the field. The authors proposed a special tool, which includes five priority areas for which it is necessary to develop a methodology for assessing creditworthiness of the borrower who seeks to implement the energy saving project. The ranking score method is quite widespread for determining the object's investment attractiveness among which is highlighted Fortune 500, Global 1000, BusinessWeek 1000 [6]. The authors are used to assess investment attractiveness based on the financial and economic performance of businesses: amount of income, profit, assets; return on investment; increase in profit, income, employees; level of market value of a business.

The assessment of investment attractiveness should account for the genetic aspect of the microeconomic system, i. e. the development potential of the business, which includes capital, technology, intellectual property, rights to use natural resources, rights to carry out activities, rights to trademarks, trade names, service marks, human resources potential, management system, information system, information, as well as for such indices as share of the aforementioned objects in the total amount of the business's assets, changes in the potential indices and its share, profitability of the aforementioned resources. The authors in [7] propose an effective enterprise risk management methodology to reduce costs and improve performance. To achieve investment success, the authors [8] suggest conducting an investment analysis using discounted cash flow or real option analysis. The authors seek to find the optimal investment strategy in the liberalized global electricity market, where the electricity price is uncertain, but other parameters are defined differently in each country. The authors propose to consider the time factors for investment and electricity price level by wind energy using the real options theory.

Almost all methods provide for the calculation of the liquidity ratio, resource use ratio, gearing ratio, profitability ratio. Occasionally, analysts determine the rate of return on equity. However, the issues of choosing and applying an effective methodology for assessing investment attractiveness of gas producers remain insufficiently worked out. The industry-based specific nature of gas producers stipulates an individual approach to analyzing performance of each business. Therefore, the analysis should account for these peculiar characteristics of their operation in order to effectively assess their performance. So, the choice and application of an effective methodology for assessing the investment attractiveness of gas industry enterprises remains inadequately worked out.

\section{Aim of research}

The aim of this research is recommendation of methodology for assessing the investment attractiveness of Ukrainian gas producers.

To achieve this aim, the main tasks of the study are the development of methodological principles for assessing the investment attractiveness of enterprises, the systematization and improvement of evaluation criteria, and the definition of the main priorities of development of gas-extracting enterprises in Ukraine.

\section{Methodology}

The general methodology of scientific research is a synergetic paradigm. Formalization and modeling methods are used to develop a system for assessing the level and efficiency of develop- 
ment of Ukrainian gas producers; grouping, comparison and description methods to determine the performance and trends of development of gas producers and investment attractiveness. The analysis methods allowed to study the resource base of Ukrainian gas industry. The first stage of determining the gas producer's attractiveness index uses the integrated index calculation method. One of the Delphi approaches - rank correlation method - is used to determine the significance of individual indices and their groups. The Delphi approach is used to select and determine the factors of business's external and internal environment.

The proposed methodology for assessing investment attractiveness of a gas producer includes the calculation of the integrated index of the level of the business's investment attractiveness by analyzing financial and economic performance of the gas producer, as well as determination of the level of the business's investment attractiveness by assessing the attractiveness of the object of interest at the meso-economic level allowing to evaluate the position of a specific business of the relevant industry and region, the impact of external and internal factors on the development of the business and the level of risks of its activities.

It is suggested that the procedure for assessing investment attractiveness of gas producers be implemented in six stages:

1. Selecting a financial performance group based on financial and accounting records;

2. Calculating static and dynamic financial performance;

3. Normalizing calculated financial performance.

4. Developing an integrated approach to assessing investment attractiveness and determining the positions of the objects of interest in terms of the level of their investment attractiveness based on the multidimensional scaling method.

At the first stage, there is a need to examine the business financial position based on the analysis of its financial and economic and accounting records. As the next step in the examination of the business's financial and economic position, it is recommended to assign the target indices to a group of indices for assessing property status, liquidity, financial stability, business activity, and profitability. It should be noted that if any index in this group falls short of the standard values, it does not need to be adjusted to calculate its rating, and if it exceeds the standard values, it does. Where the adjusted ratio is equal to a negative value, its rating is assigned a zero value. Based on the above system of indices, it is possible to determine a consolidated generalizing integrated index of investment attractiveness of businesses by the formula:

$$
\mathrm{I}=\sum_{\mathrm{j}-1}^{\mathrm{n}} \prod_{\mathrm{i}=1}^{\mathrm{n}} \mathrm{d}_{\mathrm{i}} * \frac{\left|\mathrm{x}_{\mathrm{ij}}-\mathrm{x}_{\mathrm{imax}(\min )}\right|}{\mathrm{x}_{\mathrm{imax}}-\mathrm{x}_{\mathrm{imin}}},
$$

where $x_{i j}$ is $i$-th index value; $d_{i}$ is the significance level of $i$-th index; $n$ is the number of indices; $\mathrm{x}_{\max }, \mathrm{x}_{\min }$ is the minimum or maximum value of $\mathrm{i}$-th index.

The significance level is calculated by the formula:

$$
\mathrm{d}_{\mathrm{i}}=\frac{\mathrm{R}_{\mathrm{i}}}{\mathrm{n}}
$$

where $R_{i}$ is the rating of $i$-th index according to the final ranking.

It is also proposed to use variational range for the normalization procedure [9]:

$$
z_{i}^{j}=\frac{x_{i}^{j}-x_{\text {min }}}{x_{\text {max }}-x_{\text {min }}},
$$

where $\mathrm{z}_{\mathrm{i}}^{\mathrm{j}}$ is the normalized index; $\mathrm{x}_{\mathrm{i}}^{\mathrm{j}}$ is the actual index value; $\mathrm{x}_{\max }, \mathrm{x}_{\min }$ are the minimum or maximum values of an index.

The implementation of the first stage of the methodology for assessing investment attractiveness of gas producers results in an integrated index of investment attractiveness by each business. 
Having distributed the indices by ratings from 1 to $n$ and by the degree of reduction in priority and significance, and having determined the significance of each of the five groups by aggregating the ratings of individual indices in the group, it is possible to give an objective estimate of the following ratings: the first group - 82; the second group - 280; the third group - 450; the fourth group - 410; the fifth group -200 . This is indicative of the fact that the third group of financial stability indices comes first and determines the financial safety margin of the business, i.e. stability of its activities from a long-term perspective; the group of property status indices comes second and allows to determine the sources of formation of property and assess how it is used; the group of profitability indices comes third and characterizes economic efficiency of the business's financial and economic activities; the groups of liquidity and business activity indices come fourth and fifth, respectively, and characterize the business ability to timely and fully settle its liabilities.

In the next block of assessing the business investment attractiveness, it is proposed to adjust an integrated index subject to factors that significantly affect the business's investment attractiveness: investment attractiveness at the meso-economic level; business management assessment based on cash flow analysis; effect of external risks; effect of internal risks. Therefore, the next stages of this methodology are used to select and determine the factors of business external and internal environment. External attractiveness refers to market parameters, social and economic trends in the external environment, competition within industry, reliability of buyers and suppliers. Resource potential investment attractiveness refers to production, material, innovation, financial, human, marketing, and management resources. To consider the results of assessment of industry's and region's attractiveness, the matrix of assessment of investment attractiveness at the meso-economic level presented by the authors [9] can be used subject to the aforementioned indices.

The determination of the impact of the results of all activities by the business life cycle stages enables to characterize the business internal environment, i.e. its objectives, organizational structure, planning methods, investment focus and potential investment decisions based on the life cycle stage.

To make a decision on investment, it is essential to consider information on the extent to which the intended effect can offset the risk that arises from uncertainty of the net result. Therefore, another important factor of the business investment attractiveness is the impact of certain types of risks. The degree of impact of each individual risk can be estimated only in the event of sufficient information on activities of a specific business, its relationship with the external environment and a complete description of the internal environment subject to the business life cycle. It is suggested that the assessment of the business's investment attractiveness be determined by the formula in [9].

The impact of internal and external risks on business activities and investment attractiveness is determined by the degree of impact of the respective risks $\left(R_{2}, R_{3}\right)$. According to calculations by the author, the degree of impact of risks on activities and investment attractiveness of gas producers is equal to: external $-\mathrm{R}_{1}=0.72$, internal $-\mathrm{R}_{2}=0.28$.

It should be noted that the relationship between the impact of risks and the business's attractiveness is inverse, i. e. the higher the impact of risk on the business activities, the less attractive it is. Therefore, when calculating the assessment of the business's investment attractiveness, the impact of risks should be expressed as follows: $K_{3}=1-R_{1}, K_{4}=1-R_{2}$, where $R_{1,2}$ is the impact of the respective types of risks.

When preparing and making decisions on investment projects at the sixth stage, the multidimensional scaling method will allow to combine both objective factors expressed by quantitative indices and subjective attitude of decision-makers or persons that can influence this process. Generally, the multidimensional scaling is used to identify the structure of the target set of parameters. To identify the structure means to highlight a set of major factors by which the parameters are distinguished and describe each of the parameters in terms of these factors. The procedure for building a structure is based on an analysis of objective or subjective information on their proximity between parameters or information on the benefits by a set of parameters. In this case, Minkowski metric is used [10]:

$$
d_{j k}=\sqrt[p]{\sum_{t=1}^{r}\left|x_{i t}-x_{k t}\right|},
$$


where $r$ is the space dimension; $d_{j k}$ is the distance between the dots corresponding to $\mathrm{j}$-th and $\mathrm{k}$-th parameters; $\mathrm{x}_{\mathrm{jt}}, \mathrm{x}_{\mathrm{kt}}$ are the projections of $\mathrm{j}$-th and $\mathrm{k}$-th dots on $\mathrm{t}$-th axis.

Generally, the closer the value of the business investment attractiveness to a unity, the more attractive it is for an investor.

\section{Results and Discussion}

As a result, we have identified Ukraine's gas-bearing regions, which can be considered investment-attractive in terms of the level of explored gas reserves, namely, the Eastern region, the Western oil and gas bearing region, which includes Precarpathian, Carpathian, Volyn-Podolsk oil and gas bearing regions and Transcarpathian gas bearing region; Southern oil and gas bearing region, geographically situated in Odessa, Mykolaiv, Kherson, Zaporizhzhia and partially Donetsk regions, as well as in the annexed Crimea.

Ukraine has a sufficient resource base to supply its own needs for natural gas. It has more than 120 producing gas fields [11]. The country's explored natural gas reserves are 1.094 BCM, with forecast resources accounting for 4.292 BCM. In the Black Sea and the Sea of Azov within Ukrainian exclusive economic zone, the explored natural gas reserves are estimated at 48 BCM. Almost half of the undiscovered hydrocarbon resources are associated with the Dnieper-Donets basin, where at 5 large, 20 medium and more than 500 small fields can be discovered according to scientists [12].

The use of outdated gas production stimulation technologies leads to the fact that the final weighted average ratio of extraction of the initial reserves from gas fields does not exceed 0.85 , and is even lower according to some estimates. There are currently about 2300 non-producing gas wells, although there are practically no technical or technological problems for putting them into operation.

According to the assessment of investment attractiveness, there is a need for investment in the gas production industry. Moreover, the assessment of investment attractiveness is doubled for a business that is located in an investment-attractive region and belongs to an investment-attractive industry. Using the proposed methodological approach, investment attractiveness of 10 gas producers was investigated on the basis of 24 output financial and economic factors. Based on the estimates (using the multidimensional scaling method) of values of interpreted factors, the rating of the target gas producers by level of investment attractiveness was prepared allowing to identify the most promising recipients of investment capital among them (Table 1). For the author's scale of the regional and privatization schedule - from 1 to 4, (where: 1 to behove on the a complex indicator of the level of investment attractiveness of Ukrainian gas extraction enterprises to 0.6 to $1 ; 2$ - from 0.4 to $0.59 ; 3$ - from 0.3 to $0.39 ; 4$ - from 0,1 to 0,2 ) level of investment attractiveness were divided.

Table 1

Integrated index of assessment of investment attractiveness of Ukrainian gas producers

\begin{tabular}{|c|c|c|c|c|c|c|}
\hline \multirow{2}{*}{ Business } & \multicolumn{6}{|c|}{ Integrated index, factor } \\
\hline & 2015 & LIA $^{*}$ & 2016 & LIA* & 2017 & LIA* \\
\hline PJSC UkrGasVydobuvannya & 0.605 & 1 & 0.519 & 1 & 0.598 & 1 \\
\hline PJSC Naftogasvydobuvannya & 0.542 & 2 & 0.523 & 2 & 0.562 & 1 \\
\hline PJSC Ukrnafta & 0.546 & 2 & 0.553 & 2 & 0.521 & 2 \\
\hline PJSC VK Ukrnaftoburinnya & 0.197 & 4 & 0.263 & 4 & 0.252 & 4 \\
\hline PrJSC Pryrodni Resursy & 0.423 & 2 & 0.481 & 2 & 0.467 & 2 \\
\hline Kub-Gas LLC & 0.362 & 3 & 0.314 & 3 & 0.318 & 3 \\
\hline First Ukrainian Oil and Gas Company LLC & 0.466 & 2 & 0.392 & 3 & 0.498 & 2 \\
\hline PJSC Ukrgasvydobutok & 0.591 & 1 & 0.602 & 1 & 0.521 & 1 \\
\hline Energy 95 LLC (Gravelit-21 LLC) & 0.201 & 4 & 0.132 & 4 & 0.146 & 4 \\
\hline Nadragaz LLC & 0.438 & 2 & 0.440 & 2 & 0.480 & 2 \\
\hline
\end{tabular}

Note: *LIA - level of investment attractiveness (author's calculations) 
Having analyzed the integrated index value, it may be concluded that PJSC UkrGasVydobuvannya, PJSC Naftogasvydobuvannya, PJSC Ukrnafta, Nadragaz LLC, and PJSC Ukrgasvydobutok established themselves as a leading choice.

As the members of the Association of Gas Producers of Ukraine, the state-owned company PJSC UkrGasVydobuvannya and private companies DTEK Naftogaz, Burisma, Geo Alliance Group, Smart Energy, and JV Poltava Petroleum Company together account for $88 \%$ of Ukraine's natural gas production. The purpose of the Association of Gas Producers is achieving Ukraine's energy independence by increasing equity gas production, creating a congenial investment climate, as well as transforming Ukraine from an importer into an exporter of energy resources. But, assessment of potential oil and gas exploration investments is a crucial initial step for petroleum companies to ensure the success of the investments [13]. As a result of authors' research $[11,12]$ it can be stated that Ukraine's annual gas production can grow from $20 \mathrm{BCM}$ to $27 \mathrm{BCM}$ by 2020 and exceed $30 \mathrm{BCM}$ by 2030 subject to the optimal regulatory and investment environment, thus allowing to completely abandon gas imports and ensure Ukraine's energy independence and a stable economic position in the European energy community. In the future, for example [14], it is possible to consider rating groups of regions in order to propose investment strategies for each particular region/group of regions in order to attract the most efficient investment. The authors [15] develope a group of activities, aimed at innovative development and hi-tech support has been developed.

\section{Conclusion}

1. Methodology for assessing the level of investment attractiveness of gas producers is a necessary means to meet investors' needs for obtaining comprehensive information on the current state of gas producers and prospects for their sustainable development and full information on the industry in which they operate, the level of their development in the region or industry and level of risks in the region of interest. This allows to objectively assess financial capacities of investment process since the integrated assessment enables to combine multiple factors with different names, units of measurement, significance and other characteristics in a single index. The assessment of the level of investment attractiveness of gas producers is a necessary means to meet investors' needs for obtaining comprehensive information on the current state of gas producers and prospects for their sustainable development.

2. The analysis of investment risks is instrumental in assessing investment attractiveness, internal and external characteristics of its formation. Therefore, it is recommended to conduct the analysis using statistical methods, sensitivity analysis, expert reviews, and scenario analysis.

3. The application of the methodology for assessing investment attractiveness allows to comprehensively assess the level of investment attractiveness of gas producers, which is the basis for making informed management decisions by entities involved in investment activities. Calculations of the assessment of investment attractiveness can be used in a business environment at the request of an investor or a business entity to make an investment decision. Increase in gas production output, which can further enable to solve the issue of the country's energy security and increase its level of competitiveness in the course of globalization.

\section{References}

[1] Khobta, V. M., Meshkov, A. V., Popova, O. Yu. (2005). Activation and increase of efficiency of investment processes at the enterprises. Donetsk: NAN Ukrainy, 343.

[2] Ghaiducikyi, A. P. (2004). Estimation of the investment attractiveness of the economy. Economy and Forecasting. Scientific and Analytical Journal, 3, 119-128. Availablre at: http:/eip.org.ua/docs/ EP_04_4_119_uk.pdf

[3] Chernysh, S. S. (2013). Review of the methods of analysis of investment attractiveness of the enterprise. Innovative economy, 5 (43), 87-92.

[4] Podolskaya, V., Yarish, O. (2007). Financial analysis. Kyiv: Center for Educational Literature, 488 . 
[5] Marchuk, T., Ryzhakov, D., Ryzhakova, G., Stetsenko, S. (2017). Identification of the basic elements of the innovation-analytical platform for energy efficiency in project financing. Investment Management and Financial Innovations, 14 (4), 12-20. doi: http://oi.org/10.21511/imfi.14(4).2017.02

[6] Kovaleva, N. L. (2008) Problems of Increasing Investing Attractiveness of Enterprises. Economy and Marketing in the 21st Century, 4, 55-57.

[7] Shin, I., Park, S. (2017). Integration of enterprise risk management and management control system: based on a case study. Investment Management and Financial Innovations, 14 (1), 19-26. doi: http:// doi.org/10.21511/imfi.14(1).2017.02

[8] Kinias, I., Tsakalos, I., Konstantopoulos, N. (2017). Investment evaluation in renewable projects under uncertainty, using real options analysis: the case of wind power industry. Investment Management and Financial Innovations, 14 (1), 96-103. doi: http://doi.org/10.21511/imfi.14(1).2017.10

[9] Grineva, V. M., Koyda, V. O., Lepekiko, T. I. (2005). Investment Management. Kharkiv: INZHEK, 664.

[10] Terehina, A. Ju. (1983). Multidimensional analysis of subjective data on similarities or differences. Psychology. Journ., 4 (1), 76-88.

[11] Leshchenko, I. C., Stohniy, O. V. (2015). Prospects of gas production industry in Ukraine. The Problems of General Energy, 3 (42), 5-12. doi: http://doi.org/10.15407/pge2015.03.005

[12] Vitvitsky, Ya. S., Ivanchenko, I. M. (2012). Economic problems of using the resource potential of oil extraction in Ukraine. Economy of nature management and environmental protection, 2012, 21-29. Available at: http://nbuv.gov.ua/UJRN/epod_2012_2012_5

[13] Abd. Razak, R. (2001). Assessment of Potential Oil and Gas Exploration Investments: Management Perspective. Jurnal Teknologi, 34 (1), 25-38. doi: http://doi.org/10.11113/jt.v34.655

[14] Kharlamova, G. (2014). Investment attractiveness of Ukrainian regions: rating assessment and marketing promotion. Journal of International Studies, 7 (1), 9-26. doi: http://doi.org/10.14254/2071$8330.2014 / 7-1 / 1$

[15] Bogomolova, L. L., Araslanov, R. K., Shumeyko, A. B., Buzmakov, A. V. (2015). Development of Investment Attractiveness of Oil and Gas Region in Terms of Economical Instability. Mediterranean Journal of Social Sciences, 6 (3), 221-228. doi: http://doi.org/10.5901/mjss.2015.v6n3p221 